\title{
Scientific reasoning skills based on socio-scientific issues in the biology subject
}

\author{
Muhamad Ikhwan Mat Saad 1,*, Sadiah Baharom ${ }^{2}$, Siti Eshah Mokhsein ${ }^{1}$ \\ ${ }_{1}^{1}$ Faculty of Education and Human Development, Universiti Pendidikan Sultan Idris, Tanjung Malim, Perak, Malaysia \\ ${ }^{2}$ Faculty of Science and Mathematics, Universiti Pendidikan Sultan Idris, Tanjung Malim, Perak, Malaysia
}

\section{A R T I C L E I N F O}

\section{Article history:}

Received 6 November 2016

Received in revised form

7 January 2017

Accepted 8 January 2017

\section{Keywords:}

Socio-scientific issues

Reasoning skills

Higher order thinking skills

\begin{abstract}
A B S T R A C T
Learning strategies using Socio-Scientific Issues (SSI) are approaches that will meet the characteristics of 21st Century Skills (K-21) and upgrade the Higher Order Thinking Skills (HOTS). One of the reasons of the unfavorable TIMMS and PISA results in Malaysia because students' incompetent to answer science reasoning question based on scientific issues that occur in their daily lives. SSI is a dimension that is used in the assessment of the Trends in International Mathematics and Science Study (TIMMS) and Program for International Student Assessment (PISA) which consists of the issue of the environment, medicine, health and genetic engineering. The purpose of this study is to assess the scientific reasoning level of Form Four science students in the biology subject based on SSI. Quantitative approaches surveys have been used in this study. The SSI instruments used were adapted. Total of 450 Form Four science students are samples used in this study. Findings revealed the needs of students should be discovered to levels of SSI reasoning approach because the results have shown that students' accomplishment are still low or medium level. In addition, students are incompetent to relate the concepts of science and socio-scientific issues. In conclusion, the potential of SSI approach introduced in the research and development process to enable students to master the concept of science, achieve the objectives of learning in the biology and upgrade the Higher Order Thinking. One of the implication of this research is to facilitate policy makers in implementing Biological Education Excellence in Malaysia through the development of model of Scientific Reasoning Skills.
\end{abstract}

(C) 2017 The Authors. Published by IASE. This is an open access article under the CC BY-NC-ND license (http://creativecommons.org/licenses/by-nc-nd/4.0/).

\section{Introduction}

In the $20^{\text {th }}$ century, performance evaluation in education begins with the ability of students to solve problems in a way considering the fact that have been taught by teachers through the acquisition of the basic skills of reading, writing and counting (Anat and Dori, 2003). The teachers' role at the era was as, the information sender to the students (Bransford et al., 2000). In addition, the researchers established successful students as a student who can read and given the fact the current valuation is done. However, responsive of the problems which arose beginning in the $21^{\text {st }}$ century where the student is not be able to solve the problem through the skills of

\footnotetext{
* Corresponding Author.

Email Address: aey505@gmail.com (M. I. M. Saad)

https://doi.org/10.21833/ijaas.2017.03.003

2313-626X/C 2017 The Authors. Published by IASE

This is an open access article under the CC BY-NC-ND license

(http://creativecommons.org/licenses/by-nc-nd/4.0/)
}

reasoning. Then, the elements of reasoning and thinking skills are emphasized for high level, which acquired a student who has a critical and creative thinking.

Reverse to the problems faced in Malaysia through findings of TIMMS and PISA, Malaysia positioned concurrently a country that experienced a slight decline among Southeast Asian States. For example, at PISA assessment of science in 2006, Malaysia is ranked 52 compared to 74 countries involved in the assessment. For the year 2015, this country are still experiencing to the same results of last position. Therefore, there are various conclusions that have been directed to this country, by stating the systems of school education unsuccessful prepare to compete, at the international and regional levels, especially in Science, Mathematics and Technology. Surprisingly, a report by Consultant Kestrel Education (UK) and 21st Century School (USA) confirmed that high level thinking among teachers and students in Malaysia is very low. What is High Order thinking Skills (HOTS)? 
The definition of HOTS from Ministry of Education in accordance with International Standards namely the Organization for Economic Co-Operation and Development (OECD), TIMMS and PISA, HOTS means the ability to apply knowledge, skills and values in making of reasoning and reflection for problem solving, decision making, innovative and able to create something.

The challenges to put Malaysia on par with developed countries and advanced to another, a drastic step had been taken with the introduction of the Malaysia Education Development Plan 20132015 (PPPM). Herein, the importance of PPPM thinking skills among students should be emphasized in order to produce students literate against science, mathematics and technology. This emphasis was equivalent with the Education Philosophy to produce the human capital that is balanced overall, and gained from a wide range of dimensions in terms of intellectual, spiritual, emotional and physical. The application of skills to think not only draws attention to the importance of acquiring knowledge, but each student is provided with moral and ethical knowledge to succeed in lifestyle especially in facing the challenges of the world today, across the concept of globalization.

The main problems faced by students in Malaysia is, they are not capable to answer TIMMS and PISA questions because of the elements of high-level thinking skills linked with elements of reasoning in those questions. Furthermore, requires students to associate the concept of existing knowledge through science, science literacy knowledge in their daily lives. As a result of reflection crosses examine this TIMSS and PISA, the challenging is based on current issues relating to student life (OECD, 2012). As such, the ISS is solving approach. Approach to issues of socio-scientific assimilated during the teaching and learning process in the classroom is basically unable to help students develop their skills, especially in understanding the science terms, decision making, assessment, assert the evidence and make a summary of discussions involving issues and concepts of science directly and indirectly (Sadler et al., 2004). The approach of socio-scientific issues in the classroom can help catch the attention of students to pursue science concepts more clearly (Duggan and Gott, 2002). Basically, when a teacher demonstrates, teachers try to emphasize the concept of science to be on hand, unfortunately, students lack of pay attention because of their low existing experience, the concepts could not be well delivered causing learning objectives not achieved and make students do miss conception in content knowledge (Evagorou, 2011).

The scholars established that socio-scientific issue is represented by social problems associated with human action that connects science concepts, procedures and technology that sparked controversy and warm discussed (Fleming, 1986; Kolsto, 2001; Patronis et al., 1999; Zeidler et al., 2002). Moreover, Bingle and Gaskell (1994), Driver et al. (1996), Zeidler and Keefer, (2003) revealed that SSI has gained prominence in science education because issues discussed a major role in promoting science literacy. Socio-scientific issues must involve the use of a scientific topic that requires students to contribute themselves in dialogue, discussion, and debate. These issues not only involve the controversial discussion, but as well as have additional elements that require the moral level, argument or assessment of ethics in the process of setting the decision on resolution of the possibility of these issues happen. In addition, the discussion of these issues more meaningful and significant to students personally to discuss. Indirectly, the student may submit the use of stronger evidence, reasoning and provides a path to understand systematic information (Sadler et al., 2004; Zeidler, 2003).

The objective of this study is to assess the mastery level of scientific reasoning and science students associated with the high level thinking skills-based students to SSI. Significantly, identifying the mastery level of the student, a model of scientific reasoning will be built to assess constructs a correspondence 'Goodness of Fit' that influence towards reasoning scientific students and expected potential SSI approach introduced in the R\&D process to enable students to master the concept of science, meeting the objectives of learning in the subject biology and upgrade the High Thinking Skills Level. The implications of this research can facilitate policy makers in implementing biological education in Malaysia.

\subsection{Reasoning and biological subjects based on SSI}

In the description of the form four Biology Syllabus has emphasized scientific and skills in critical-thinking skills. So, to link, each topic taught to narrate to the skills to be achieved. Then, the approach of SSI is introduced because this approach not only requires reasoning theories, but makes the students critically thinks by implementing communication skills as debating. There are many topics that can be linked with the socio-scientific issues in subject. Four among them have been identified, which are chemical composition within cells, Organization Cell Nutrition, Dynamic Ecosystems and Endangered Ecosystems.

In this regard, every discussion or arguments involving socio-scientific issues demand the elements of reasoning and analysis skills. Scientific reasoning should be applied to students because of the mastery of these skills enable to them become a professional scientist. According to Newmann (1990), students whom exposed to high-level thinking can challenge themselves to interpret, analyze or manipulate the information given by the teacher. The mastery of scientific reasoning is a skill that requires students to elucidate every issue occurrence, and every explanation requires to scientific evidence. If each answer is analyzed and accompanied by evidence, then the student has 
mastered the level of scientific reasoning. In investigating matters relating to issues of socioscientific, reasoning deductive or informal reasoning is used because it involves the submissions rather than to analyst data simply (Sadler et al., 2004). Meanwhile, the questioning of SSI is different from the questioning of other science concepts, more structured and the difficulty debated is the solution that has a variety of perspectives. In contrast to formal reasoning, or reasoning inductive, each solution through discussions involving problem solving more complex (Kuhn, 1991; Means and Voss, 1996; Perkins et al., 1991). In an article by Zohar and Nemet (2002), they explained the concept of scientific reasoning involves thinking need to cause and effect, the pros and cons, pros or cons, motion-a motion to resolve problems or other alternatives. This is in line with the questions addressed in this study in which requires students to reasoning and analyzes the answers provided by them. In addition, SSI involving reasoning can increase understanding of science concepts taught, so instead if reasoning less, subsequently a science concept is also low (Tytler et al., 2003; Fleming, 1986; Hogan, 2002; Zeidler and Schafer, 1984).

\subsection{HOTS and reasoning skills in $21^{\text {st }}$ century}

If formerly teachers often thought that mastery of HOTS and reasoning will solely occur in exceptional students merely, while moderate and weak could not be qualified of master the basic facts (Zohar et al., 2001). According to the Bloom taxonomy, students are skillful in analyze, synthesize and evaluate is students who have high level thinking while students who are able to commit to memory and reproduce the fact remembered by them are categories of thought the low level.

Every human being has a variety of different ways in decision making. Everything is based on sources that are searched and known. As shown in the 'Model' Reflective Judgment that everyone has an understanding and knowledge of different natural. Then, this person will make the reflection and the justification of knowledge. Table 1 shows a comparison between the reflection models (Piaget, 1972; Perry, 1999; King and Kitchener, 1994) which involve scientific reasoning.

Table 1: Comparison models of scientific reasoning were adapted from Peter (2014)

\begin{tabular}{|c|c|c|c|}
\hline RS Level & Piaget & Perry & $\begin{array}{l}\text { King and } \\
\text { Kitchener }\end{array}$ \\
\hline Low & Concrete & Dualism & Pre-reflective \\
\hline Medium & Transitional & Multiplicity & Quasi-reflective \\
\hline High & Formal & Relativisms & Reflective \\
\hline
\end{tabular}

Recently, problem solving associated with the use of information technology to obtain procedure resources, enhance in the debate or discussion. Significant study was done by NCREL (2003), defining $21^{\text {st }}$ Century skills as very significant skills in students to fit into the rapid transform almost. $21^{\text {st }}$ century skill is very influential in produce students and employees to meets the requirements of the industry. Paradigm shift needs to be immediately implemented in the educational system to ensure that such skills are dominated by educators and students so that they may be served with more comprehensive and continuous. Therefore, the education system needs to understand and appreciate the skills of the 21st century to be applied into the academic context as a whole. Partnership for $21^{\text {st }}$ Century Skills says between the characteristics of the students of the 21st century is to have and master 1) Reasoning skills, 2) Problem-solving skills, 3) Communication skills and 4) Collaborative Skills.

\section{Methodology}

This study uses the quantitative method in the survey of 450 students' science form four. Set of instruments that were used in this study was in the written test form to assess scientific reasoning science students' level. This instruments form has three different scenario discusses the socio-scientific issues of adaptation. According to Bell and Laderman (2003), this instrument has been through the validity process of the six experts namely four teachers and two scientists. The scenario is common and can be questioned is answered by students stating the reason for decision making, in addition to save time during the actual administrative process later. This instrument refers to the dimensions of reasoning which consists of three scenarios, for scenarios I (climate change) and II (Nutrition) there are five sub questions and for scenario III (smoking and cancer) there are 3 sub questions. Table 2 shows the example question scenario III through the issue of smoking and cancer that are administered to students.

To analyze scientific reasoning questions to students, rubric analysis submissions in complex reasoning have been implemented (Tal et al., 2013; Zohar and Nemet, 2002). Table 3 shows the scored and scheme answers for student reasoning. This focused response students Rubrics who support their argument by stating each justification and explains its mechanism.

Rubric given score will refer to the scientific level score of reasoning. Score this same level of reasoning with research carried out by Perry (1999), King and Kitchener (1994) which involves scientific reasoning. Scheme of scoring in determining the level of scientific reasoning is as shown in Table 4 (Lawson and Wollman, 2003).

\section{Results and discussion}

Data shows the level of scientific reasoning of form four students who take the Biology Subject is still low. A total of 78\% (351 students) answer the scenario given is in low level; while 19\% (85 students) were in moderate and only $3 \%$ (14 students) are in high level (Table 5). 
Table 2: Examples of scientific reasoning questions for scenario III

\begin{tabular}{|c|c|c|}
\hline $\begin{array}{l}\text { Scenario } \\
\text { III }\end{array}$ & \multicolumn{2}{|c|}{$\begin{array}{l}\text { Many researchers believe that smoking accounts for a large proportion of all cancers and as much as } 30 \% \text { of all cancer deaths. Cigarette smoking } \\
\text { specifically been implicated as the cause of cancer of the lung, oral cavity, larynx, esophagus, bladder, kidney, and pancreas. Additionally, the ris } \\
\text { developing cancer is greater for people who smoke more and who start smoking at a younger age. Furthermore, researchers believe that smoking } \\
\text { be the cause of } 25-30 \% \text { of all heart disease. Exposure to passive tobacco smoke is very likely a significant cause of cancer in non-smokers. Son } \\
\text { scientists believe that the increased risk could be as high as } 50 \% \text {. It has been estimated that thousands of people die each year due to exposure } \\
\text { passive cigarette smoke. Recently, nicotine in cigarette tobacco has been identified as a drug whose addictiveness exceeds that of opium and hero } \\
\text { addition to this, documents have come to light that indicate that some tobacco companies have used a variety of methods to increase the amount } \\
\text { potency of nicotine in cigarette tobacco. Finally, it has been shown that many people begin smoking as teenagers, and once started, have a very dif } \\
\text { time quitting. In contrast to these claims, tobacco companies have consistently asserted that while tobacco may be associated with increased ris } \\
\text { various cancers and heart disease, it has never been proven to cause these diseases. Furthermore, to smoke or not is a free choice that should be } \\
\text { the consumer, not government agencies. }\end{array}$} \\
\hline $\begin{array}{l}\text { Sub } \\
\text { questions }\end{array}$ & $\begin{array}{l}\text { 3a. Given the reported } \\
\text { 3b. Would you support } \\
\text { 3c. Do the alleged d }\end{array}$ & $\begin{array}{l}\text { oke and its addictiveness, should legislation be passed that would make cigarette smoking illegal? } \\
\text { or why not? } \\
\text { t more difficult for minors to obtain cigarettes and/or penalizes tobacco compa nies who target mi } \\
\text { in their advertising? Why or why not? } \\
\text { atte smoke justify banning smoking in public places such as restaurants and bars? Why or why not }\end{array}$ \\
\hline \multicolumn{2}{|c|}{ able 3: Shows the score and scheme answers to students reasoning (Zohar a } & $\begin{array}{r}\text { answers to students reasoning (Zohar a } \\
\text { Reasoning Score }\end{array}$ \\
\hline & $\begin{array}{l}0 \\
1 \\
2 \\
3 \\
4 \\
5\end{array}$ & $\begin{array}{c}\text { No answer or No justification in context of question } \\
\text { One justification of decision: mechanism unelaborated } \\
\text { Two or more justifications of decision: mechanisms unelaborated } \\
\text { One justification of decision: mechanism explained with examples } \\
\text { Two or more justifications of decision: one mechanism explained } \\
\text { Two or more justifications of decision: multiple mechanisms explained }\end{array}$ \\
\hline
\end{tabular}

This outcome in line with some other findings that show that Malaysian students in schools and universities is weak in scientific reasoning skills. The results of this study shown Malaysian students has less capable of high level scientific reasoning than students in the United States. This decision is very significant is it different because at the 20th Century, other countries such as the United States has set the level of reasoning scientific students. Study of Lawson and Wollman (2003) at the age of 16 years reported that $22 \%$ of respondents have a high level scientific reasoning, 59\% are at moderate and 19\% at a low level.

Table 4: Shows a scheme of the score and the level of scientific reasoning

\begin{tabular}{cc}
\hline Score & The Level of Scientific Reasoning \\
\hline $0-1$ & Level 1 (low-pre reflection) \\
$2-3$ & Level 2 (moderate-quasi reflection) \\
$4-5$ & Level 3 (high-reflection) \\
\hline
\end{tabular}

Table 5: Number of percentage according to the level of students' scientific reasoning

\begin{tabular}{cccc}
\hline Score & The Level of Scientific Reasoning & The Number of Students & Percentage (\%) \\
\hline $0-1$ & Level 1 (low) & 351 & 78 \\
$2-3$ & Level 2 (medium) & 85 & 19 \\
$4-5$ & Level 3 (high) & 3 & 3 \\
\hline
\end{tabular}

In addition, the pattern of answers obtained from students shown they use the knowledge contained within the confines, and they only managed to comment on the confines of the scenario given in the questions only. They dominate the pre-reflection stage only (level 1). For example the question presented;

Given the reported dangers of cigarette smoke and its addictiveness, should legislation be passed that would make cigarette smoke illegal? Why yes or why not?" Students simply replied, "Yes, it is necessary because smoking may increase mortality."

Students' answers with do not reflect the context of reasoning that requires to justification, data on the number of deaths and the mechanism of death or how smoke happens. Stage of quasi reflection and reflection is not happening on this student. They lack knowledge and understanding of their associates in decision making. According to Sadler et al. (2004), training debate needed in problem solving involving levels of reasoning. When analyzing individual will use the knowledge gained from other sources and provide evidence to strengthen all the knowledge discussed.
Also in this study, researchers have also measure the difference in comparison to decide in which category did not answer directly 6\% (27 students) or answered "Yes" and "No" as much as 3\% (14 students), then the comparison is to decide "Yes" 84\% (378 students) or "No" 7\% (31 students) only. Table 6 shows a comparison of the results have been answered by the students. Answer "Yes" or "No" does not show an error to the students but the students how to justify and response mechanisms are taken into account to determine the level of student RS.

The result of this analysis shows students without any problems support and reaches agreement to each of the questions asked, to match the findings of Bell and Laderman (2003), where students continue to set an agreement with the scenario given, just that distinguishes it is the level of reasoning students when answering the questions given. Thus, to get the answer a student who has the consent and have reflection, then a strategy of socioscientific issues should be disclosed to students who take the subject of biology in order to improve the 
content, concepts of science and make reflection (Zeidler and Nichols, 2009).

Table 6: Shows a comparison in a decision making

\begin{tabular}{cccc}
\hline Category of Decision & Number of Students & Percentage (\%) & Note \\
\hline No answers & 27 & 6 & No need to analysed \\
"Yes" & 378 & 84 & Analysed \\
"No" & 31 & 7 & Analysed \\
"Yes" and "No" & 14 & 3 & No need to analysed \\
Total & 450 & 100 & - \\
\hline
\end{tabular}

\section{Conclusion}

To sum up, in order to produce students who have reasoning skills and higher level thinking, students need to be exposed to reasoning skills in classroom or teaching approach. Strategy of SSI is very suitable taught to students in the biology subject, as a result of the discussions and decisions made are able to make students, more focused, reflection of making skills corresponding to current issues in their daily lives. Zimmerman (2005) stressed it is important to carry out fundamental research related to understanding scientific reasoning skills among students that can be used to build a better teaching model. Indirectly, to expose students to become familiar reading questions and answers with more resourceful. In order to produce excellent students in this reasoning, especially in making reflection, strategies and approaches, discussion of SSI needs to emphasize so that students is not only can find answers to a problem and solving decision-making but can practice in their daily life. Its hope that these SSI strategies can be applied in biology curriculum and can be translated in the form of modules for the use of teachers and students.

\section{References}

Anat Z and Dori YJ (2003). Higher order thinking skills and lowachieving students: Are they mutually exclusive? Journal of the Learning Sciences, 12(2): 145-181.

Bell RL and Lederman NG (2003). Understandings of the nature of science and decision making on science and technology based issues. Science Education, 87(3): 352-377.

Bingle WH and Gaskell PJ (1994). Scientific literacy for decision making and the social construction of scientific knowledge. Science Education, 78(2): 185-201.

Bransford JD, Brown AL, and Cocking RR (2000). How people learn: Brain, mind, experience, and school. National Academy Press, Washington DC, USA.

Driver R, Leach J, Millar R, and Scott P (1996). Young people's images of science. Open University Press, Buckingham, UK.

Duggan S and Gott R (2002). What sort of science education do we really need?. International Journal of Science Education, 24(7): 661-679.

Evagorou M (2011). Discussing a socio-scientific issue in a primary school classroom: The case of using a technology supported environment in formal and non-formal settings. In: Sadler TD (Eds.), Socio-Scientific Issues in the Classroom: Teaching, Learning and Research: 131-160. Springer, Amsterdam, Netherlands.

Fleming G (1986). Chemical applications of ultrafast spectroscopy. Oxford University Press, UK.
Hogan K (2002). Small groups' ecological reasoning while making an environmental Management decision. Journal of Research in Science Teaching. 39(4): 341-368.

King PM and Kitchener KS (1994). Developing reflective part: Understanding and promoting intellectual growth and critical thinking in adolescents and adults. Jossey-Bass Conventional Publishers, California, USA.

Kolsto SD (2001). Scientific literacy for citizenship: Tools for dealing with the science dimension of controversial socio scientific issues. Science Education, 85(3): 291-310.

Kuhn D (1991). The skills of argument. Cambridge University Press, Cambridge, England.

Lawson AE and Wollman WT (2003). Encouraging the transition from concrete to formal cognitive functioning-an experiment. Journal of Research in Science Teaching, 40 (Suppl.): 33-50.

Means ML and Voss JF (1996). Who reasons well? Two studies of informal reasoning among children of different grade, ability, and knowledge levels. Cognition and Instruction, 14(2): 139178.

Newmann FM (1990). Higher order thinking in teaching social studies: A using for the assessment of classroom thoughtfulness. Journal of Curriculum Studies, 22(1): 41-56.

North Central Regional Educational Laboratory (NCREL) (2003). Engage 21st century skills: Literacy in the Digital Age. Available online at: http://pict.sdsu.edu/engauge21st.pdf.

Organisation for Economic Co-operation and Development (OECD) (2012). PISA 2012 technical report programme for international student assessment. OECD Publishing, Paris, France.

Patronis T, Potari D, and Spiliotopoulou V (1999). Students' argumentation in decision-making on a socio-scientific issue: Implications for teaching. International Journal of Science Education, 21(7): 745-754.

Perkins DN, Farady M, and Bushey B (1991). Everyday reasoning and the roots of intelligence. In: Voss JF, Perkins DN, and Segal JW (Eds.). Informal Reasoning and Education: 83-105. Lawrence Erlbaum Associates Inc, New Jersey, USA.

Perry WG (1999). Forms of intellectual and ethical development in the college years: A scheme. Jossey-Bass Publishers, California, USA.

Peter AD (2014). Science and society: Scientific thought and education for the 21st century. Jones and Barlett Learning, Massachusetts, USA.

Piaget J (1972). Intellectual evolution from adolescence to adulthood. Human Development, 15(1): 1-12.

Sadler TD, Chambers FW, and Zeidler DL (2004). Student conceptualizations of the nature of science in response to a socio scientific issue. International Journal of Science Education, 26(4): 387-409.

Tal R, Dori YJ Keiny S, and Zoller U (2013). The conceptual change of teachers beginning in STES education and curriculum development-The STEMS Project Approach. International Journal of Science Education, 23(3): 247-261.

Tytler R, Duggan S, and Gott R (2003). Dimensions of data analysis, the public understanding of science and science education. International Journal of Science Education, 23(8): 815-832. 
Zeidler DL (2003). The role of moral reasoning and the status of socioscientific issues in science education. Springer, Amsterdam, Netherlands.

Zeidler DL and Keefer M (2003). The role of moral reasoning and discourse on socio scientific issues in science education. In: Zeidler DL (eds.), The Role of Moral Reasoning and the Status of Socioscientific Issues in Science Education: Philosophical, Psychological and Pedagogical Considerations: 7-38. Springer, Amsterdam, Netherlands.

Zeidler DL and Nichols BH (2009). Socioscientific issues: Theory and practice. Journal of Elementary Science Education, 21(2): 49-58.

Zeidler DL and Schafer LE (1984). Identifying mediating factors of moral reasoning in science education. Journal of Research in Science Teaching, 21(1): 1-5.
Zeidler DL, Walker KA, Ackett WA, and Simmons ML (2002). Tangled up in views: Beliefs in the nature of science and responses to socioscientific dilemmas. Science Education, 86(3): 343-367.

Zimmerman C (2005). The development of scientific reasoning skills: What psychologists contribute to an understanding of elementary science learning? Available online at: http://sites.nationalacademies.org/cs/groups/dbassesite/do cuments/webpage/dbasse_080105.pdf.

Zohar A and Nemet F (2002). Fostering students' knowledge and argumentation skills through dilemmas in human genetics. Journal of Research in Science Teaching, 39(1): 35-62.

Zohar A, Degani A and Vaaknin E (2001). Teachers about low achieving students and higher order thinking. Teaching and Teachers' Education, 17(4): 469-485. 